視床下部性甲状腺機能低下, 性腺機能低下症に高 $\mathrm{Na}$ 血症を 伴つた下垂体後葉機能不全症の 1 例

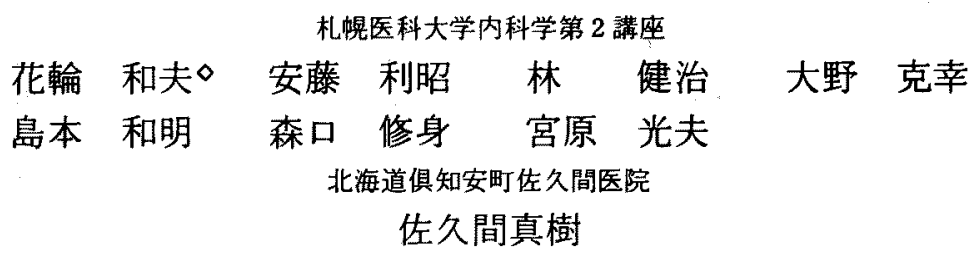

\title{
A CASE OF HYPOTHALAMIC HYPOTHYROIDISM, HYPOGONADISM AND DIABETES INSIPIDUS ASSOCIATED WITH HYPERNATREMIA
}

\author{
Kazuo Hanawa, MD, Toshiaki Ando, MD, Kenji Hayashi, MD, Katsuyuki Ohno, MD \\ Kazuaki Shimamoto, MD, Osami Moriguchi, MD and Mitsuo Miyahara, MD \\ Department of Internal Medicine (Section II), Sapporo Medical College \\ Masaki SAKUMA, MD \\ Sakuma Hospital in Kuchan, Hokkaido
}

\begin{abstract}
椳要 視床下部性甲状腺機能低下，性腺機能低下症に，高Na血症を伴つた極めて希なる1例を経験 したので報告する。症例は25才の女性. 12 才初潮.16才上り月経不順，食欲不振，やせ，多领，多 尿出現. 19才上り無月経. 22 才頃上り多飲, 多尿消失. 内分泌学的精查を求めて入院. 入院時, 体 温，血王低く，徐脈を呈する．外性器には異常ない，血清 $\mathrm{Na} 158 \mathrm{mEq} / l, \mathrm{Cl} 115 \mathrm{mEq} / \mathrm{l}$. 甲状腺機 能は低値を示すが，TSH，TRH陚験は正常反応. 性腺機能は尿中エストロダン，総ゴナドトロピンは

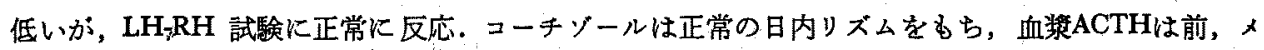
チラポン負荷後も正常値を示す。その他の前葉機能として, 成長ホルモンは基整値, インスリン負荷

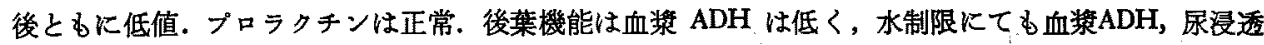
圧の上昇はない，Cater-Robbins試験では尿量の減少なく，ビトレシンで尿量の減少，尿浸透圧の上昇 をみた，以上から，視床下部病変儿基つくく状腺，性腺機能低下症と後葉機能不全症と診断．さら に多飲の傾向がないことから, 渴中枢の障害を思わせる. 神経症状なく, 視力, 視野 眼底, トルコ 鞍, 脳シンチに異常はない，䯣液は正常，その他の諸桧査成績からす，現在のところ如何なる視床下 部病变かは明らかにしえなかつた.なお，高Na血症の機序につき若干の考察を加えた。
\end{abstract}

はじめに

下垂体ペプチドホルモンである, thyroid stimulating hormone(TSH), luteinizing hormone( $\mathrm{LH})$,

〔昭和50年 9 月 6 日 第116回北海道地方会推鹤〕 follicular stimulating hormone (FSH) のradioimmunoassayの普及と, 合成視床下部遊離ホルモン の臨床応用が 可能 となり, 下垂体予備能検査と しての応用が確立し, 視床下部性の病変と, 下垂 体性の病変との鑑別が可能となつた ${ }^{122)}$. その結 
果, 最近, 視㦿下部性甲状腺機能低下症 ${ }^{8 / 4)}$, 視 床下部性性腺機能低下症 ${ }^{5)}$, 視床下部性沉下垂体 機能低下症 ${ }^{637)}$ の報告が散見されるようになつ た. 一方，中权性高Na血症について内外に多数の 報告がみられ，それらの原因は視床下部に存在 するとされている渴中权, anti diuretic hormone (ADH) 分泌中枢の異常に基づくと考光られてい $3^{8)}$.

今回，われわれは，視床下部に原因があると思 われる甲状腺機能低下，性腺機能低下症に，高 $\mathrm{Na}$ 血症を合併した下垂体後葉機能不全症の極めて希 な 1 例を経験したので，文献的考察を加えて報告 する。

\section{患者：【, 25才，主婦。}

主訴：全身倦总感, 無月経.

家族歴：特記すべきことなし。

既往憷：身体発育や知能に特別な異常なく， その他特記すべきことなし。

現病歴：昭和 41 年 (16才) 春頃より, 漸次, 食欲不振，や世，全身隐急感が出現，同時に口 渴, 多飲, 多尿を認め, 寒さにも敏感となつた。 月経は12才で初潮，以後月経は16才まで順調で あつたが，この頃より2〜3カ月に 1 回ぐらいと 不規則となり，44年（19才）春頃より無月経とな つた. 46年（22才） 9 月頃より食欲不振，や甘， 全身倦急感が増悪し，某医を受診し，低血圧，低 体温，貧血を指摘され，治療により症状は幾分軽 減. 又, この頃上り多飲, 多尿の傾向が消失し始 め, 現在は全くない４9年（24才） 2 月頃より黄 疸, 浮腫を認め, 某院に入院. 約 1 力月で症状改 善, 入院中，一時ブロゲステロン療法で月経の発 来をみたが，内分泌学的精查を求めて 6 月17日当 科六院した。

入院時現症：身長 $156.6 \mathrm{~cm}$, 体重 $51.5 \mathrm{~kg}$ で体 格中等度. 栄養は良. 視力, 精神機能に異常な く，皮䖉は乾燥状で椧たいが，色素沈着を認めな い，甲状腺は触知しない，体温は $35.5^{\circ} \mathrm{C}$ と低く， 脈拍整， 1 分間 48 条脈を示し，血王 $84 / 52 \mathrm{mmHg}$
と低い，胸部，腹部に特記すべき所見はない，乳 房の発育は正常であるが，恥毛，腋毛は，媡であ る、浮腫なく、神経学的所見にも異常を認めず， 視野狭窄むない，尿量は 1 日約 $1800 \mathrm{ml}$.

\section{入院時検查成績}

一般臨床検查（表 1)：末梢血で正色素性筫 血を呈し，血沈は中等度に元進している，検尿で は比重低下以外異常ない。肝機能では，GOT, GPTが中等度に高く, アルカリフォスファターゼ (alk-P-ase) $\gamma$-GTP 高值を示し, 肝生検では慢 性肝炎の組織像を示した. 入院後, 2 回の肝機能 の増悪をみている，䇾機能はFishberg濃縮試験で の尿比重の低下をみる。電解質では高 $\mathrm{Na}$ ，高 $\mathrm{Cl}$ 血 症を呈する。血清脂質では, 総コレステロール, トリグリセライド，リン脂質は高值を示す，血浆 レニン活性は $6.84 \mathrm{ng} / \mathrm{ml} / \mathrm{h}$ ，血浆アルドステロンは $28.4 \mathrm{ng} / \mathrm{dl}$ と何れも高い。循環血浆量は $77.6 \mathrm{ml} /$ $\mathrm{cm}-\%$ normalで低值．血浆浸透圧は $318.5 \mathrm{mOsm} / l$ と高值である。

胸部 $\mathrm{X}$ 線像には異常はない，心電図ではPQ時 間0.20秒，四肢誘導で電位が軽度に低い以外とく に異常を認めない。

内分泌学的検查（表 2)：

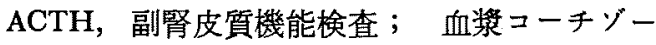
ルは正常の日内変動を示すが，午後はやや低値で ある(図 1-1).メチラポン試験では，尿中17OHCSは前値，負荷後もやや低い傾向を示すが， 血浆ACTHは前値, 負荷後の最大值は 3 倍以上で, ともに正常である。 $\beta^{1-24} \mathrm{ACTH} 0.5 \mathrm{mg}$ 静注後の血 殞コーチゾールは正常な反応を示す（図1ー2）.

甲状腺機能検查； $\mathrm{T}_{8}$ レジンスポンジ摂取率, 血将 $\mathrm{T}_{4}$ 值, 基礎代謝率と何れる低值である。 ${ }^{181} \mathrm{I}$ 摂取率も低いが，TSH試験では正常反応を示す。 TRH試験での血数TSHは，後半やや反応が遅延し ているが正常反応である（図 1-3）.

性腺機能検査；基礎体温は二相性でなく，不 規則である。尿中エストロゲン，尿中プレグナン ディオールともに低值．尿中ゴナドトロピンも低 い. LH-RH試験では血浆 LH，FSHは正常反応を 


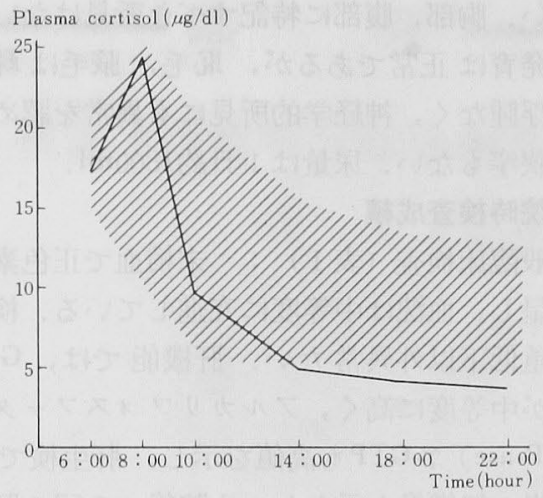

図 1-1，血獎コーチゾルの日内変動

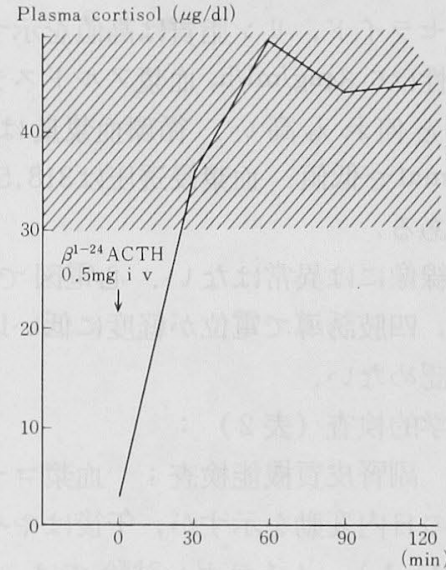

図 1-2，急速ACTH試験

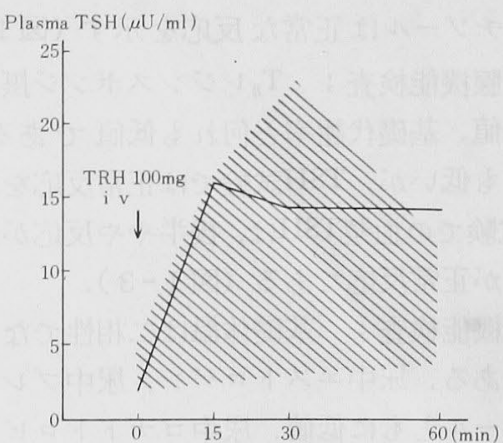

図 $1-3 . T R H$ 試験

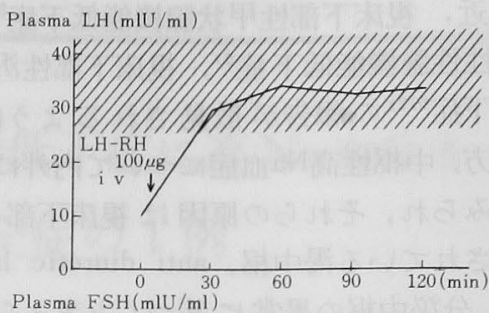

Plasma $\mathrm{FSH}(\mathrm{mlU} / \mathrm{ml})$

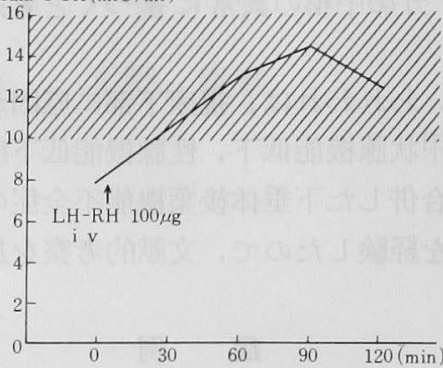

図 1-4，LH-RH試験

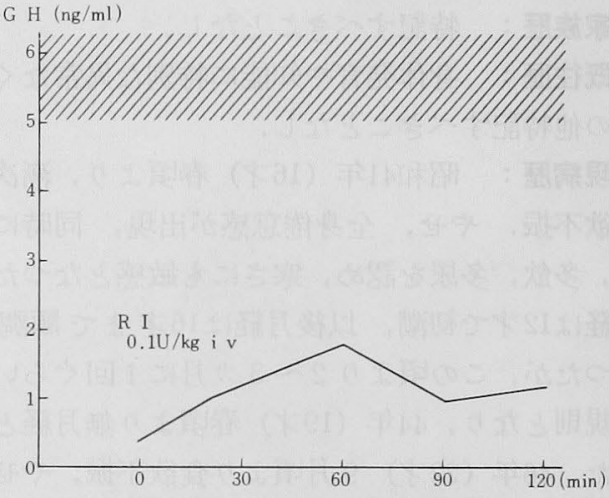

図1-5４ンスリン負荷試験

Plasma PRL $(\mathrm{ng} / \mathrm{ml})$

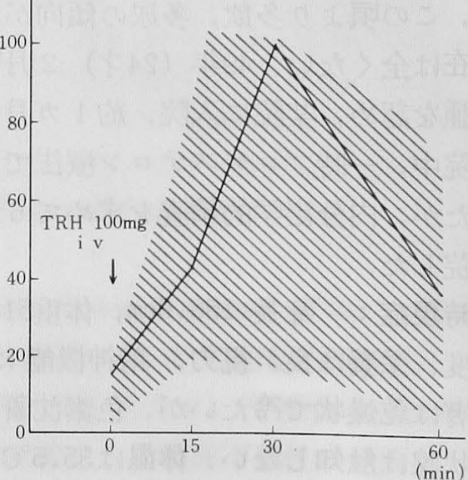

図1-6.TRHに対するプロラクチンの反応試験 
表 1 . 一般臨床検査成績

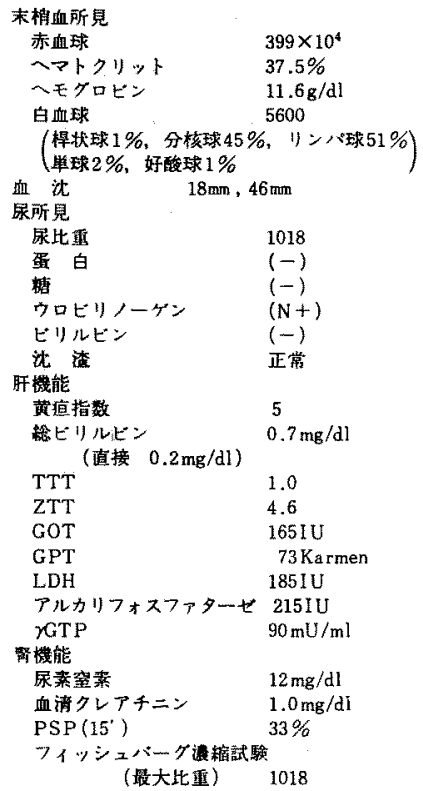

\begin{tabular}{|c|c|c|}
\hline \multicolumn{3}{|c|}{ 血消電解俩 } \\
\hline $\mathrm{Na}$ & \multicolumn{2}{|c|}{$158 \mathrm{mEq} / l$} \\
\hline $\mathrm{K}$ & \multicolumn{2}{|c|}{$4.4 \mathrm{mEq} / \mathrm{l}$} \\
\hline $\mathrm{Cl}$ & \multicolumn{2}{|c|}{$115 \mathrm{mEq} / \mathrm{l}$} \\
\hline $\mathrm{Ca}$ & \multicolumn{2}{|c|}{$9.2 \mathrm{mEq} / l$} \\
\hline $\mathrm{P}$ & \multicolumn{2}{|c|}{$3.4 \mathrm{mEq} / l$} \\
\hline \multicolumn{3}{|c|}{ 衁清脂公 } \\
\hline \multicolumn{2}{|c|}{ 舲コレステロール } & $298 \mathrm{mg} / \mathrm{dl}$ \\
\hline & $225 \mathrm{mg} / \mathrm{dl}$ \\
\hline & & $0.30 \mathrm{mEq} / \mathrm{l}$ \\
\hline \multicolumn{2}{|c|}{ リン指賈 } & $304 \mathrm{mg} / \mathrm{dl}$ \\
\hline \multicolumn{3}{|c|}{ 血清䚈白分画 } \\
\hline \multicolumn{2}{|c|}{ 剩嬖自 } & $7.2 \mathrm{~g} / \mathrm{dl}$ \\
\hline \multicolumn{2}{|c|}{ アルフミン } & $66.0 \%$ \\
\hline \multicolumn{2}{|c|}{$\alpha_{1}$ ダロプリン } & $2.0 \%$ \\
\hline \multicolumn{2}{|c|}{$a_{2}$ グロブリン } & $9.0 \%$ \\
\hline \multicolumn{2}{|c|}{ 乎ロフリン } & $8.5 \%$ \\
\hline \multicolumn{2}{|c|}{ yグロフリン } & $14.5 \%$ \\
\hline \multicolumn{2}{|c|}{ CRP } & $(-)$ \\
\hline \multicolumn{2}{|l|}{$\mathrm{RA}$} & $(-)$ \\
\hline \multicolumn{2}{|c|}{ ASLO } & 500 \\
\hline \multicolumn{2}{|c|}{ 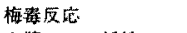 } & $(-)$ \\
\hline \multicolumn{2}{|c|}{ 血箖レニン活性 } & $6.84 \mathrm{ng} / \mathrm{ml} / \mathrm{h}(0.30-2.80)$ \\
\hline \multirow{2}{*}{\multicolumn{2}{|c|}{ 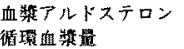 }} & $28.4 \mathrm{ng} / \mathrm{dl}(4.0-18.5)$ \\
\hline & & $77.6 \mathrm{ml} / \mathrm{cm}-\%$ normal $(85-115)$ \\
\hline \multicolumn{2}{|c|}{ 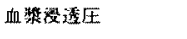 } & $318.5 \mathrm{mOsm} / /(285-295)$ \\
\hline
\end{tabular}

表 2. 内分泌学的検查成績

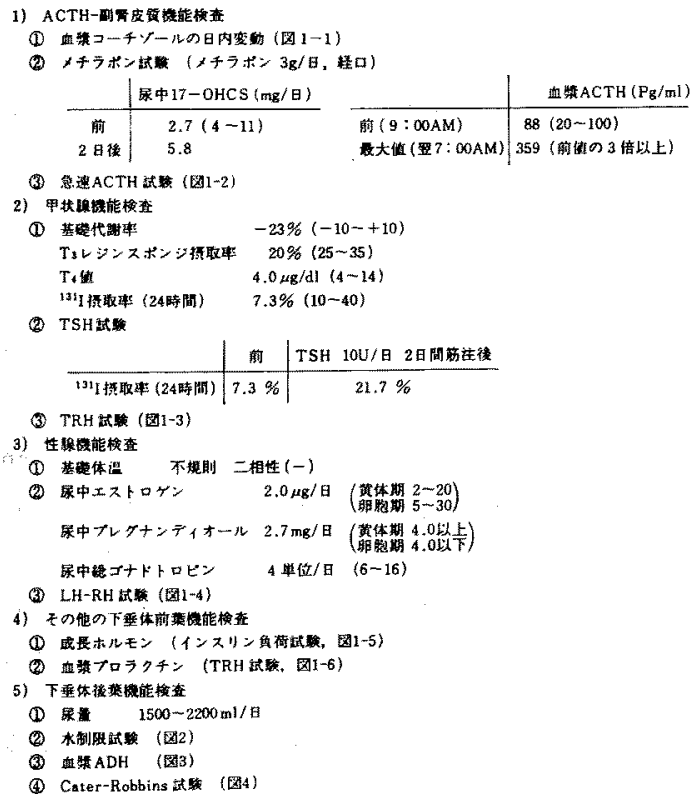

呈している(図 1-4).

その他の下垂体前葉機能検査；成長ホルモン (GH) はインスリン負荷試験での反応は低下して

いる（図 1-5）。血浆 プロラクチンは前，TRH 静注後の反応ともに正常である（図 1-6）.

下垂体後葉機能検查； 8 時間水制限試験の尿 浸透圧の経過を図 2 に示すが，水制限でも尿浸透 正の上昇はみられない，又，血浆ADHは前 1.5 $\mathrm{pg} / \mathrm{ml}$ と低く，16時間水制限です $2.0 \mathrm{pg} / \mathrm{ml}$ と充分 な上昇が認められない（図 3 ). Cater-Robbins試 験では尿量の減少，尿浸透王の上昇がなく，ピト レシン 0.1 単位で尿量の減少，尿浸透圧の上昇を みた（図 4).

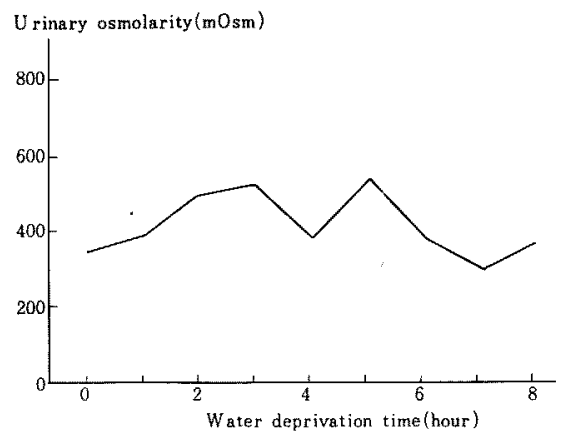

図 2, 水制限試験 


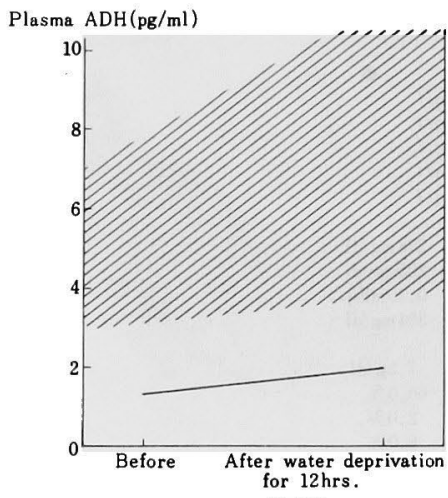

図 3. 血獎 $\mathrm{ADH}$

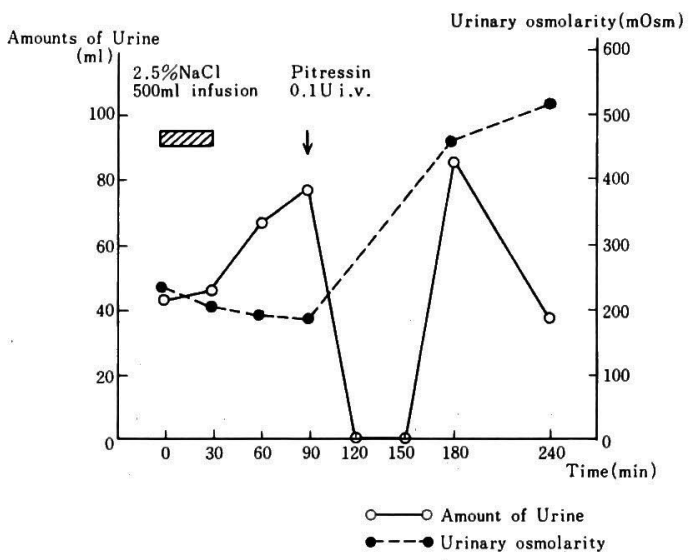

図 4. Cater-Robbins試験

その他の検査 :

トルコ鞍X線像； 破壊像拈よび異常石灰化像 は認めない.

脳, 脊髄液; 初圧 $150 \mathrm{mmH}_{2} \mathrm{O}$, 無色清澄, 比 重1006, 細胞数3/3 (リンパ球), 総たん白 $31 \mathrm{mg} / \mathrm{dl}$, グロブリン $15 \mathrm{mg} / \mathrm{dl}$, 糖 $56 \mathrm{mg} / \mathrm{dl}$, 塩素 $121 \mathrm{mEq} / l$, ト リプトファン反応 (一) で, 何れる異常はない。

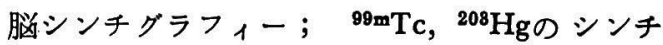
グラムに異常所見はない。

眼底; うつ血乳頭, 白斑, 出血などの異常を 認めず，正常である。

\section{入院後の释過}

甲状腺機能低下症に 対して，チロナミン $10 \mu \mathrm{g}$
より開始し，漸次 $80 \mu \mathrm{g}$ をで増量したが， $\mathrm{T}_{\mathbf{8}} 22.9$ $\%, \mathrm{~T}_{4}$ 值 $4.5 \mu \mathrm{g} / \mathrm{dl}$, 基礎代謝率一 $16 \%$ とな打機能 低下を示し，チラジン15mgを併用し， $\mathrm{T}_{8} 22.9 \%$ ， $\mathrm{T}_{4}$ 值 $7.6 \mu \mathrm{g} / \mathrm{dl}$, 基礎代謝率+ $5.5 \%$ とほぼ正常化 した. 他方, 月経の発来なく, 又, インスリン負 荷でのGHの反応も低下したままである．血清電 解質はNa $150 \sim 158 \mathrm{mEq} / l, \mathrm{~K} 3.7 \sim 5.3 \mathrm{mEq} / l$, Cl $110 \sim 118 \mathrm{mEq} / l$, 尿量も 1 日 $1500 \sim 2200 \mathrm{ml}$ を示 していた. 患者は, 甲状腺機能が正常化とともに 全身倦总感が消失し，動作も活発となり，50年 3 月退院し，51年 9 月の現在でも健康で家事仕事に 従事している.

\section{考案}

視床下部障害による下垂体機能低下症につい て,Bauer'は，過去の文献により19例の視床下部 病変にもとづく性腺機能低下症の剖検例, Fisher $ら^{10)}$ は視床下部の血管病変, Selenkowら ${ }^{11}$ はザル コイドージスによる沉下垂体機能低下症のそれぞ れ 1 例を報告している.下垂体ペプチドホルモン のradioimmunoassayの確立と, 合成視床下部遊離 ホルモンの臨床応用が可能となり，甲状腺機能低 下症が 従来の原発性, 下垂体性以外飞, 視床下 部に基づくものが存在すると考えられ，1971年 Pittmanら ${ }^{3)}$ が初めてその 1 例を報告し，視床下部 性甲状腺機能低下症と命名した。そして，本例の 診断基準として，(1) 甲状腺機能低下，(2) 正常 または低いTSH値，(3) TRHに対する正常なTSH の増量の 3 点をあげている. 翌年, Shenkmanら は同様の 2 例を報告している．乙かし，Pittman ら ら4)症例のうち 1 例はTSHの他にゴナドトロピ ンおよびGHの欠損をもち，他の 1 例ではADH 低下によるNa代謝障害を伴つている．また, TRH 単独欠損による甲状腺機能低下例も報告されてい $る^{12)}$. 一方, 視床下部, 下垂体異常による性腺機 能低下症としてのゴナドトロピン単独欠損例の 報告が散見されるが，この原因が視床下部か， 下垂体にあるか従来明らかでなかつた．1972年 Hashimoto ら5)は初めて LH-RH 試験により視床 
下部性性腺機能低下症の1 例を 報告 した。さら

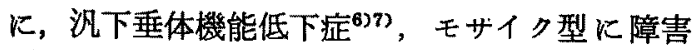
された報告例として，上記報告例以外に，ADH，

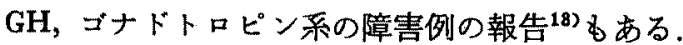

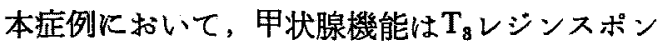
ジ摂取率， $\mathrm{T}_{4}$ 值，基礎代謝率， ${ }^{281}$ 掑取率が低く 機能低下を示しているが，血浆TSH濃度は低く， TSH試験で131I摂取率は正常に上昇したことより 原発性機能低下症は否定される。また，血浆TSH 濃度は前值が低いが，TRH試験にて良好な反応を 示すことから，下垂体性甲状腺機能低下症ではな $く$, Pittmanら のいら視床下部性甲状腺機能低 下症と思われる。

性腺機能にかんしては，初潮から16才まで月経 は正常であつたこと，プロゲステロン寮法で月経 の発来をみていること,ささらに尿中総ゴナドトロ ピンが低值であることより，原発性機能低下は考 えがたい，また，甲状腺機能低下症による性腺機 能低下は，甲状腺ホルモン補充療法で甲状腺機能 が正常化したにかかわらず月経の出現をみない点 から否定される。性腺機能低下症の原因として は，血浆FSH，LHはLH-RH試験に正常に反応し ていることより視床下部病変によるものと推察さ れる。

さらに，下垂体前葉機能では，血䟥コーチゾー ルが正常の白内リズムをもち, メチラポン負荷に より血浆ACTHは正常に反応しているので，視床 下部一下垂体一副腎皮質系は障害がないものと考 えられる。他方， $\mathrm{GH}$ は基礎值も低く，インスり ン刺激試験です反応せず，GH分泌能の低下があ る.このインスリン刺激は, 神経系を介して視床 下部に直接働き，GHを遊離する(1)ことから， GH 分泌能の低下は下垂体障害というより，むしろ 視床下部から遊離されるGH-releasing hormone の障害があると推定される。下垂体プロラクチ ンは視床下部からのprolactin-release inhibiting factor (PIF) に上り抑制されており，PIF の遊 離障害があると，血球プロラクチンは高值を示す といわれている15). また，TRHによる血粶プロラ
クチンの增加は，下垂体茥切断を受けた患者です 認められることから，下垂体に対する直接作用と 考えられている ${ }^{16)}$. 本例は基礎値が正常であるこ とからPIFの障害を思わせないし，さらに，TRH に正常に反応したことから下垂体でのブロラクチ ン分泌能は正常に保たれているといえる。

他方，下垂体後葉機能は，本例では，16才より 21 才にかけて存在した多领, 多尿は現在はみられ ないが，尿比重，尿浸透压が低下し，血浆ADHは 低值を示している．また，水制限です尿浸透王の 上昇，尿量の減少はなく，血漿 $\mathrm{ADH}$ 正常以上の 上昇を認めない。そして，Cater-Robbins試験で は，尿量の減少がなく，ピトレシンで尿量の減 少，尿浸透圧の上昇を示した。このことから，心 因性多尿，腎性尿崩症は否定される。また，䯣液 所見その他の諸検査成績から, 脳腫瘍, 結核, 䯣 膜炎，外傷などの続発性尿崩症を考えらる原因が なく，特発性尿崩症といえよう。

さらに，本例惊Na血症を伴い，血浆浸透圧の 上型にすかかわらず，多领の傾向がないことは， 渴中枢の障害を疑わせる。渴中权と $\mathrm{ADH}$ 分泌中权 は，視床下部で近い位置にあるか，あるいは一部 重視していることが実験的に推定されておりり ${ }^{17)}$, 渴中枢の障害とADH分泌不全が 同時飞括こり易 く，脱水が生じて高Na血症にひきおこすと考え られている。そして，循環血浆量の低下によるレ ニン・アンジオテンシンの作動, さらにはアルド ステロン分泌が元進し，高Na血症がさらに増長 されるのではないかと推定される。 Trustら ${ }^{18)} は$ は, 松果体腫瘍による沉下垂体機能低下症に尿崩症を 伴つた 1 例で，初期は多领，多尿を認めたが，経 過が進む従い，渴中枢の障害が生し，多领の傾 向がなくなつて脱水がおこり，循環血浆量の低下 によつて，血中アンジオテンシンが増加して尿量 の低下をうながしたと推論している. 即ち，彼ら， は，経過中の血中アンジオテンシン值と尿量の減 少とがよく一致し，アンジオテンシンが尿量の低 下に原因していると考光ている，本症例 す ADH の分泌不全があるにもかかわらず尿量がそれはど 
多くないのは，渴中枢障害により循環血冰量が低 下し，それがレニン，ひいてはアンジオテンシン の上昇，さらにアルドステロンの上昇をひきおこ し，多尿の出現しない一因となつていると考党ら れる。

以上により，本例は視床下部病変にもとづく， TSH，LH，FSH，GH，ADHの低下を示すモザイ ク型の機能低下と，渴中枢障害による高 $\mathrm{Na}$ 血症 を認めた。このように視床下部性甲状腺機能低下 および性腺機能低下症に，高Na血症を伴つた下 垂体後葉機能不全症例は, われわれの調べる限り 内外の報告にみられず，極めて希有と思われる．

視床下部の器質的病変としては, 腫瘍が圧倒的

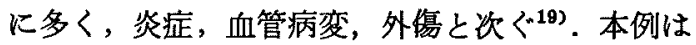
神経症状がなく, 視野, 視力, 眼底, 髄液, 脑シ ソチグラフィー,トルコ鞍X線像にも異常なく， また，発症から10年間脳圧元進症状るなく腫瘍は 考え難い，また，炎症，血管障害，外傷も経過お よび諸検査成績より否定的であり，原因にかんし て今のところ不明であるが，今後の経過を詳細に 検索して原因を追求する予定である.

\section{まとめ}

25才の女性で，合成視床下部遊離ホルモンの負 荷試験により，視床下部性甲状腺機能低下および 性腺機能低下症に, 高Na血症を伴つた下垂体後 葉機能不全症の極めてまれなる1例を経験し，こ れに文献的考察を加光た。な敃視床下部病変が如 何なるるのかは明らかにしえなかつた。

この症例を報告するにあたり，ホルモンの一部を测定 していたたいた本学第一内科, 泌尿器科, 産㖊人科教室 の教室員各位に深謝する。

\section{文献}

1) Gugal, C, et al: Clinical experience with hypothalamic releasing hormones. Part 1 . Thyrotropin-releasing hormone. Recent Progr Horm Res 28: 173, 1972. - 2) Kastin, AJ, et al: Release of LH and FSH after administration of synthetic LH-releasing hormone. $J$ clin Endocrinol Metab 34: 753, 1972. -3) Pittman, JA Jr, et al: Hypo- thalamic hypothyroidism. New Engl J Med 285: 844, 1971. 4) Shenkman, L, et al: Triiodothyronine and thyroid stimulating hormone response to thyrotrophin-releasing hormone. A new test of thyroidal and pituary reserve. Lancet $\mathrm{i}: 111,1972$. -5) Hashimoto, $T$, et al: Isolated gonadotropin deficiency with response to luteinizing- hormonereleasing hormone. New Engl J Med 287: 1059, 1972. -6) Woolf, PD, et al: Hypopituitarism secondary to hypothalamic insufficiency. Ann Inter Med 78: 88, 1973. -7) Strauss, JH, et al: Hypothalamic hypopituitarism in an adolescent girl: Assessment by a direct function test of the andreno hypophysis. J clin Endocrinol Metab 39: 639, 1974. -8) 吉利 和, 他：中权性電解質異常の症 例と成立機転一高 $\mathrm{Na}$ 血症を呈した松果体腫煌の 1 例一。本臨床 $22: 19,1964$. -9) Bauer, HG： Endocrine and metabolic conditions related to pathology in the hypothalamus. A review. J Nerv Ment Dis 128: 323, 1958. - 10) Fisher, ER and Hellstrom, HR: Pathologic findings in a case of panhypopituitarism and diabetes insipidus. Arch Path 66: 282, 1958. -11) Selenkow, HA, et al: Hypopituitarism due to hypothalamic sarcoidosis. Amer J Med Sci 238: 456, 1959. -12) 吉本祥 生, 他: TRH 単独欠損症. 日本臨床 $32: 2405$, 1974，一13）小橋 喬，他：結核性䯇獏炎に上る尿 崩症ならびに部分的下垂体前㷛機能低下症をきた した 1 例. 最新医学 $30: 864,1975$. - 14) Greenwood, FC and Landon, J: Assessment of hypothalamic pituitary function in endocrine disease. $J$ clin Path 19: 284, 1966. -15) Turkigton, RW, et al: Elevated serum prolactin levels after pituitary-stalk section in man. New Eng J Med 285: 707, 1971._-16) Lister, RC, et al: Evidence for a direct effect of thyrotropin-releasing hormone (TRH) on prolactin release in humans. $J$ clin Endocrinol Metab 39: 1148, 1974. -17) Goldberg, M, et al: Hyponatremia and the inappropriate secretion of antidiuretic hormone. Amer $\mathrm{J}$ Med 35: 293, 1963. - 18) Trust, PM, et al: A case of hypopituitarism with diabetes insipidus and loss of thirst. Role of antidiuretic hormone and angiotensin II in the control of urin flow and osmolarity. $J$ clin Endocrinol Metab 41: 346, 1975. -19) 宇尾野公義, 田辺等: 視床下

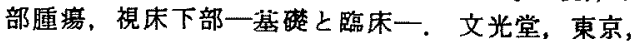
1966, pp. $408 \sim 438$. 